\title{
Resistive Exercise versus Acupressure on Blood Glucose Level in Type 2 Diabetes
}

\author{
AMANY Y. AHMED, M.Sc.*; AKRAM A. SAYED, Ph.D.*; NAGI L. NASIF, Ph.D.* and \\ ABO EL NAGA EL HAGAGY, M.D.** \\ The Department of Physical Therapy for Cardiovascular Respiratory Disorder and Geriatric*, Faculty of Physical Therapy, \\ Cairo University and Internal Medicine**, Faculty of Medicine, Cairo University
}

\begin{abstract}
Background: Type 2 diabetes has become a major global public health concern characterized by dysregulation of carbohydrate, lipid and protein metabolism, and results from impaired insulin secretion, insulin resistance or a combination of both Abstract: Acupressure lowers the blood glucose level through a massage at the point of the meridian, which can trigger the calming and uplifting response in the body, Resistive exercise is often recommended for patients with type 2 diabetes to improve physical conditioning and glycemic control.
\end{abstract}

Aim of Study: The current study was conducted to compare between: Effect of resistive exercise and Acupressure on blood glucose level in type 2 diabetes.

Subjects and Methods: Sixty patients (34 male 26 female) with type 2 diabetes participated in this study their age ranging from 35 to 60 years. They were selected from outpatient clinic in Internal Medicine, Luxor General Hospital. Group A: Received acupressure therapy (AT on point (Sp-6) which found atone palm width above the tip of inner ankle bone on the back of the shinbone, 3 minutes and repeated 3 times per session on both legs for three times per week for 12 weeks, in addition to hypoglycemic drugs. Group B: Received resistive exercise using dumbbell and sandbag, intensity of exercise for each muscle group determined after assessment of ten repetition maximum (10RM) $40 \%$ to $60 \%$ of $1 \mathrm{RM}$ (1 set 10 repetitions) used for 30 minute 3 time per week for 12 week beside their medication. 10RM reevaluated every 2 week and after 2 week load increase to 2 set 10 repetitions. Method of evaluation was measurement of random blood glucose level measured before starting and after each session glycosylated hemoglobin (HbA1c) fasting blood glucose level, 2 hour post prandial and glucose level and insulin level measured before starting and after end of program.

Results: There was a significant decrease in randomized blood glucose, fasting blood glucose and increase in insulin level with no significant differences in HA $1 \mathrm{C}$ and 2 hour post prandial in acupressure group when compared with resistive exercise group.

Correspondence to: Dr. Amany Y. Ahmed, The Department of Physical Therapy for Cardiovascular Respiratory Disorder and Geriatric, Faculty of Physical Therapy, Cairo University
Conclusion: Acupressure is more effective than resistive exercise as a complementary alternative medicine \& can be helpful in reducing blood glucose level and increasing insulin levels in type 2 diabetic patients.

Key Words: Acupressure-Diabetes mellitus - Resistive exercise training.

\section{Introduction}

TYPE 2 diabetes is a long term metabolic disorder that is characterized by high blood sugar, insulin resistance, and relative lack of insulin. Common symptoms include increased thirst, frequent urination, and unexplained weight loss. Symptoms may also include increased hunger, feeling tired and sores that do not heal. Often symptoms come on slowly. Long term complications from high blood sugar include heart disease, stroke, diabetic retinopathy which can result in blindness, kidney failure and poor blood flow in limbs which may lead to amputations. The sudden onset of hyperosmolar hyperglysmic state may occur, however, ketoacidosis is uncommon [1].

The pathogenesis of type 2 diabetes is progressively impaired insulin secretion by pancreatic 0 cells, usually upon a background of pre-existing insulin resistance in skeletal muscle, liver and adipose tissue. Overt hyperglycaemia is preceded by prediabetes, a high risk condition that predisposes individuals to T2DM development [2].

Type 2 diabetes imposes a substantial physical and psychological burden on patients, resulting in reduced health status and Quality of life [3].

Resistive exercise is reported to be safe and effective in the management of type 2 diabetes. Resistance training reported to promote insulin 
sensitivity via increased muscle mass, glucose uptake, and facilitate glucose clearance from the circulation. High-intensity progressive resistance training [PRT, 75-85\% 1-repetition maximum $(1 \mathrm{RM})]$ has been shown to be safe for older diabetic patients, and improved glycemic control (decreased $\mathrm{HbA1c}$ ) and muscle strength. Furthermore, RE can be performed in a residential setting and is more appropriate for sedentary, elderly T2D patients with worse muscle strength [4].

Acupressure therapy appears to be an effective non pharmacological adjunctive treatment for alleviating the development and progression of T2Drelated complications results from the secretion of neurotransmitters which regulate the function of glands and, consequently, different organs through the transmission of nerve messages or stimulation of the hypothalamic-pituitary-adrenal axis; in addition, it is believed that acupressure can affect the regulation of blood sugar through body relaxation and stress reduction [5].

\section{Subjects and Methods}

Sixty patients ( 34 male 26 female) who had type 2 diabetes participated in this study. Their ages ranged from 40 to 60 years. The participants were selected from outpatient clinic in Internal Medicine of Luxor General Hospital. The study was conducted over six months from May 2019 till November 2019. The patients were randomly assigned into two equal groups (30 patients for each group):

Group A (Acupressure group): This group includes 30 patients with type 2 diabetes who received acupressure therapy beside their medication, 3 minutes and repeated 3 times per session on both legs for three times per week the treatment was conducted for 12 weeks ( 3 times/week).

Group B (Resistive exercise group): This group includes 30 patients with type 2 diabetes who received resistive exercise beside their medication using dumbbell and sandbag, used for 30 minute 3 time per week for 12 week.

The potential participants were excluded if they had cardiopulmonary diseases, peripheral vascular diseases or they werw drugs abuse or alcohol intake.

\section{Equipment used:}

1- Measurement tools:

- Weight-height scale: It was used to measure weight and height for each subject in groups before starting the study to calculate the body mass index $\left(B M I=k g / \mathrm{m}^{2}\right)$.

- The Random blood glucose monitoring: Prepare the testing strip and glucose monitor to be ready for the blood sample Record the time, blood sugar reading, and recent food intake in a log.

- The HbA1c test test measures the amount of blood sugar (glucose) attached to hemoglobin. It's a three-month average because that's typically how long a red blood cell lives.

- Fasting and two hour post prandial glucose monitoring in lab require: Fasting no consumption of food at least 8 hour before test. 2 hour post prandial two hour after eating.

- Insulin level: In lab need blood sample.

\section{2- Therapeutic equipment:}

Resistive training program used free weights in the form of sand bags and dumbbell $(1 / 2,1$, and 2 kilos) for large muscle groups of the lower limbs and different graduations for the trunk muscles.

\section{Procedures of the study:}

Measurement procedures:

- Weight-height scale: Measure weight and height for each subject in groups measure body mass index for each patient weight in kilograms divided by the square of height in meters

- Random blood glucose monitoring: By Preparing the testing strip and glucose monitor to be ready for the blood sample, cleaning the testing area usually the side of a fingertip, using an alcohol swab.

Lance the testing area. Bracing against a firm surface can help with the impulse to pull away Squeeze in the testing area around the wound to maximize blood flow, Squeezing a drop of blood onto the test strip, Putting the strip into the monitor Record the time, blood sugar reading, and recent food intake in a log.

- The HbA $1 \mathrm{c}$ test.

The person underwent this test in a labA hemoglobin $\mathrm{A} 1 \mathrm{c}(\mathrm{HbA} 1 \mathrm{c})$ test measures the amount of blood sugar (glucose) attached to hemoglobin. An Hb1c test showed what the average amount of glucose attached to hemoglobin has been over the past three months [6].

- Fasting 2 hour post prandial glucose monitoring: Patient fasting 12 hour before test recording fasting blood glucose level foe 2 hour post prandial patient consume breakfast or lunch containg 100 gram carbohydrates draw 2 hour after meal. 
- Insulin level: Test to measure amount of insulin in the blood.

\section{3- Treatment procedures:}

During the 12 week intervention period, Resistive training program for group B used free weights in the form of sand bags and dumbell for large muscle groups of the lower limbs and different graduations for the trunk muscles. All subjects started the exercise program at 40 to $60 \%$ of 10 repetition maximum load for a given exercise for a total of 10 repetitions (one set). After one entire circuit (consisting of 8 sets, one set for each muscle group) was completed, a second circuit of exercises was performed on lower limb exercises. To maintain the appropriate intensity for these exercises, muscle testing was repeated for these muscles every 2 weeks. So, adjustments in weights (for the lower limb muscles) or graduations (for the trunk muscles) were made every 2 weeks throughout the duration of the study to continue increases in strength. The weights were added to or replaced with heavier weights or graduations when the person could achieve $>10$ repetitions. Subjects alternated between upper and lower body exercises to minimize fatigue, with approximately 2 -minute rest between exercises with no rest between repetition Sand bags of different weights $(1 / 2,1$, and 2 kilos) made were used.

Acupressure therapy: Group A received acupressure (AT on point (Sp-6) which found atone palm width above the tip of inner ankle bone on the back of the shinbo.

\section{Statistical analysis:}

Analysis of data was done using Statistical Program for Social Science version 20 (SPSS Inc., Chicago, IL, USA). Quantitative variables were described in the form of mean and standard deviation. Qualitative variables were described as number and percent. In order to compare parametric quantitative variables between two groups, Student $t$ test was performed. Qualitative variables were compared using chi-square $\left(\mathrm{X}^{2}\right)$ test or Fisher's exact test when frequencies were below five. Pearson correlation coefficients were used to assess the association between two normally distributed variables. When a variable was not normally distributed, A $p$-value $<0.05$ is considered significant.

\section{Results}

Distribution of patients height, weight and BMI:

Patient height in group (A) with mean \pm S.D. $168.77 \pm 4.539 \mathrm{~cm}$ while in group (B) with mean \pm S.D. $166.03 \pm 3.961 \mathrm{~cm}$. There was no statistically significant differences between groups where $p=0.565$.

Patients weight in group (A) with mean \pm S.D. $95.43 \pm 14.009 \mathrm{~kg}$ while in group (B) with mean \pm S.D. $95.47 \pm 8.772 \mathrm{~kg}$. There was no statistically significant differences between groups where $p=0.991$.

Patients body mass index in group A with mean \pm S.D. $33.509 \pm 4.710 \mathrm{~kg} / \mathrm{m}^{2}$ while in group (B) with mean \pm S.D. $34.68 \pm 3.424 \mathrm{~kg} / \mathrm{m}^{2}$. There was no statistically significant differences between groups where $p=0.276$ Hemoglobin A1C before intervention (HA1C):

Patients HA1C in group (A) with mean \pm S.D. $9.853 \pm 1.424$ while in group (B) with mean \pm S.D. $9.557 \pm 1.608$. There was no statistically significant differences between groups where $p=0.452$.

\section{Hemoglobin Al C after intervention (HAl C):}

Patients HA1C in group (A) with mean \pm S.D. $8.90 \pm 1.044$ while in group (B) with mean \pm S.D $9.14 \pm 1.379$. There was no statistically significant differences between groups where $p=0.457$.

\section{Random Blood Sugar (RBS) before intervention:}

Patients FBS in group (A) with mean \pm S.D. $210.173 \pm 26.960$ while in group (B) with mean \pm S.D. $194.707 \pm 23.324$. There was no statistically significant differences between groups where $p=0.391$.

\section{Random Blood Sugar (RBS) after intervention:}

Patients RBS in group (A) with mean \pm S.D. $194.900 \pm 14.752$ while in group (B) with mean \pm S.D. $188.600 \pm 25.095$. There was statistically significant differences between groups where $p=0.001$ with decreasing of RBS in group (A) than Group (B).

\section{Fasting Blood Sugar (FBS) before intervention:}

Patients FBS in group (A) with mean \pm S.D. $166.173 \pm 26.960$ while in group (B) with mean \pm S.D. $161.707 \pm 23.324$. There was no statistically significant differences between groups where $p=0.495$.

\section{Fasting Blood Sugar (FBS) after intervention:}

Patients FBS in group (A) with mean \pm S.D. $146.900 \pm 14.752$ while in group (B) with mean \pm S.D. $165.600 \pm 25.095$. There was statistically significant differences between groups where $p=0.001$ with decreasing of FBS in group (A) than Group (B). 


\section{2 hours post prandial before intervention:}

Patients 2 hours post prandial in group (A) with mean \pm S.D. $264.8 \pm 33.281$ while in group (B) with mean \pm S.D. $269.83 \pm 40.638$. There was no statistically significant differences between groups where $p=0.602$.

\section{2 hours post prandial after intervention:}

Patients 2 hours post prandial in group (A) with mean \pm S.D. $205.3 \pm 17.448$ while in group (B) with mean \pm S.D. $211.567 \pm 12.230$. There was no statistically significant differences between groups where $p=0.113$.

\section{Serum Insulin Level before intervention:}

Patients Serum Insulin Level in group (A) with mean \pm S.D. $11.894 \pm 3.821$ while in group with mean \pm S.D. $13.139 \pm 3.315$. There was no statistically significant differences between groups where $p=0.183$.

\section{Serum Insulin Level after intervention:}

Patients Serum Insulin Level in group (A) with mean \pm S.D. $17.70 \pm 5.038$ while in group (B) with mean \pm S.D. $13.600 \pm 4.149$. There was statistically significant differences between groups where $p=0.001$ with increasing of serum insulin level in group (A) than Group (B).

\begin{tabular}{llll}
\hline & $\begin{array}{c}\text { Group (A) } \\
(\mathrm{n}=30)\end{array}$ & $\begin{array}{c}\text { Group (B) } \\
(\mathrm{n}=30)\end{array}$ & $p$-value \\
\hline Height Mean \pm S.D & $168.77 \pm 4.539$ & $166.03 \pm 3.961$ & 0.565 \\
Weight Mean \pm S.D & $95.43 \pm 14.009$ & $95.47 \pm 8.772$ & 0.991 \\
BMI Mean \pm S.D & $33.509 \pm 4.710$ & $34.68 \pm 3.424$ & 0.276 \\
HA1C before intervention Mean \pm S.D & $9.853 \pm 1.424$ & $9.557 \pm 1.608$ & 0.452 \\
HA1C after intervention Mean \pm S.D & $8.90 \pm 1.044$ & $9.14 \pm 1.379$ & 0.457 \\
(RBS) before intervention Mean \pm S.D & $210.173 \pm 26.960$ & $194.707 \pm 23.324$ & 0.391 \\
(RBS) after intervention & $194.900 \pm 14.752$ & $188.600 \pm 25.095$ & 0.001 \\
(FBS) before intervention Mean \pm S.D & $166.173 \pm 26.960$ & $161.707 \pm 23.324$ & 0.495 \\
(FBS) after intervention Mean \pm S.D & $146.900 \pm 14.752$ & $165.600 \pm 25.095$ & 0.001 \\
2HS post prandial before intervention & $264.8 \pm 33.281$ & $269.83 \pm 40.638$ & 0.602 \\
2HS post prandial after & $205.3 \pm 17.448$ & $211.567 \pm 12.230$ & 0.113 \\
Serum insulin level before intervention & $11.894 \pm 3.821$ & $13.139 \pm 3.315$ & 0.183 \\
Serum insulin level after intervention & $17.70 \pm 5.038$ & $13.600 \pm 4.149$ & 0.001 \\
\hline
\end{tabular}

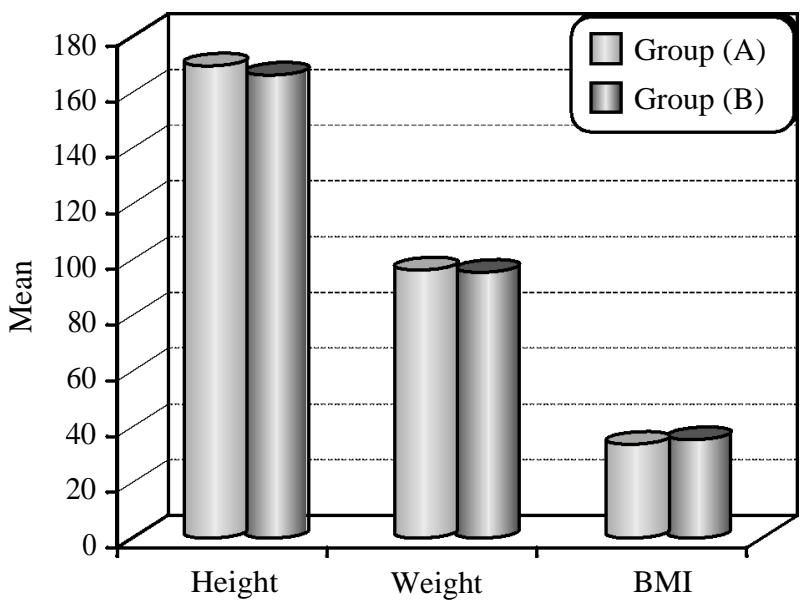

Fig. (1): Comparison between two groups as regard to height, weight and BMI.



Fig. (2): Comparison between two groups as regard to patient's HA1C before intervention. 


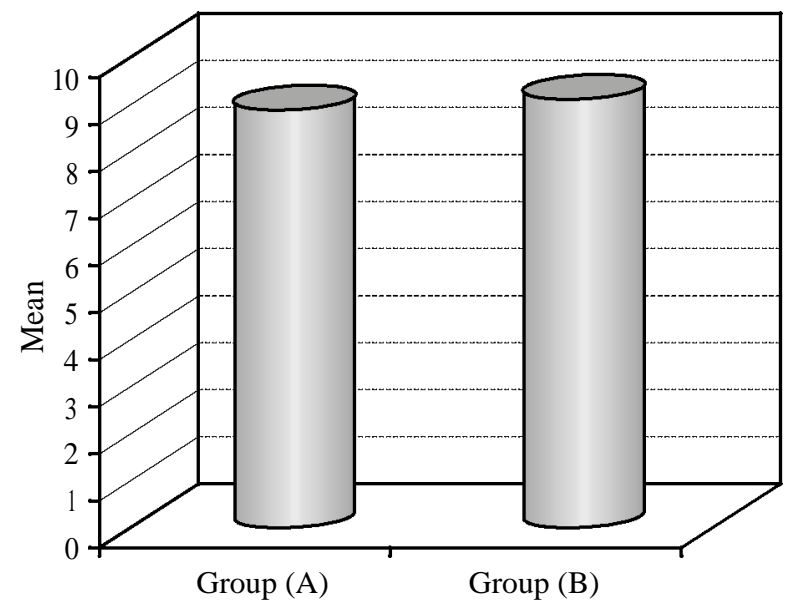

Fig. (3): Comparison between two groups as regard to patient's HA1C after intervention.

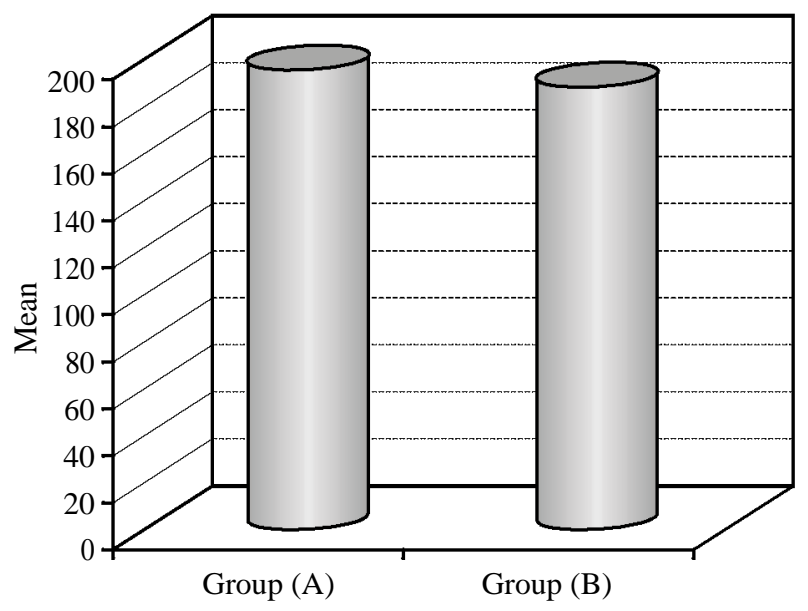

Fig. (5): Comparison between two groups as regard to patient's RB S.

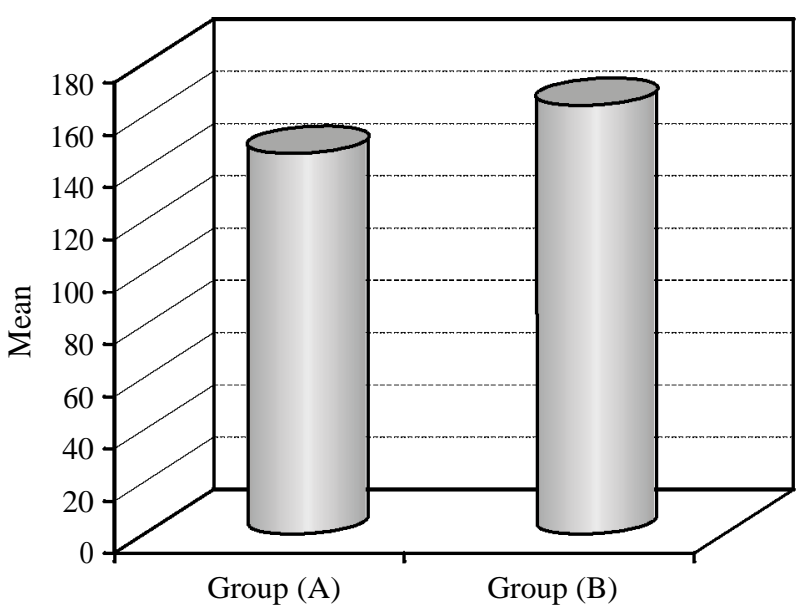

Fig. (7): Comparison between two groups as regard to patient's FBS after intervention.

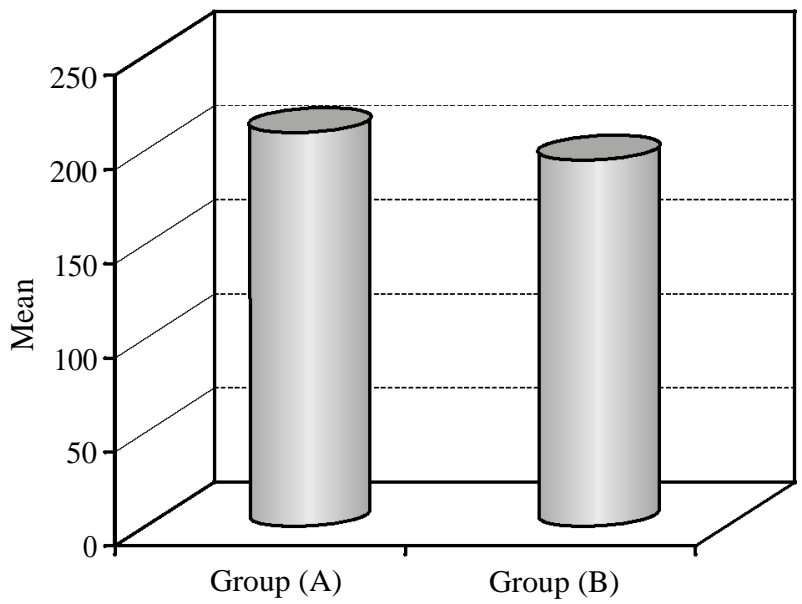

Fig. (4): Comparison between two groups as regard to patient's RBS before intervention.

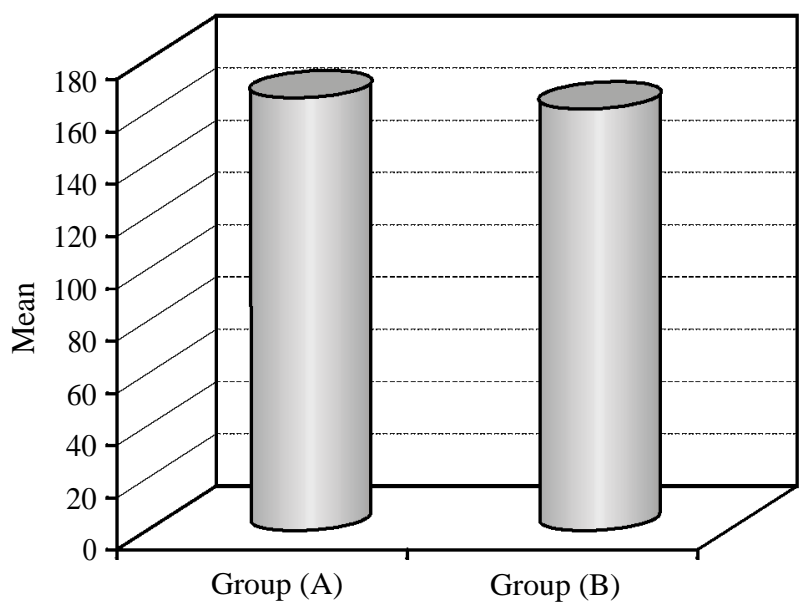

Fig. (6): Comparison between two groups as regard to patient's FBS before intervention.

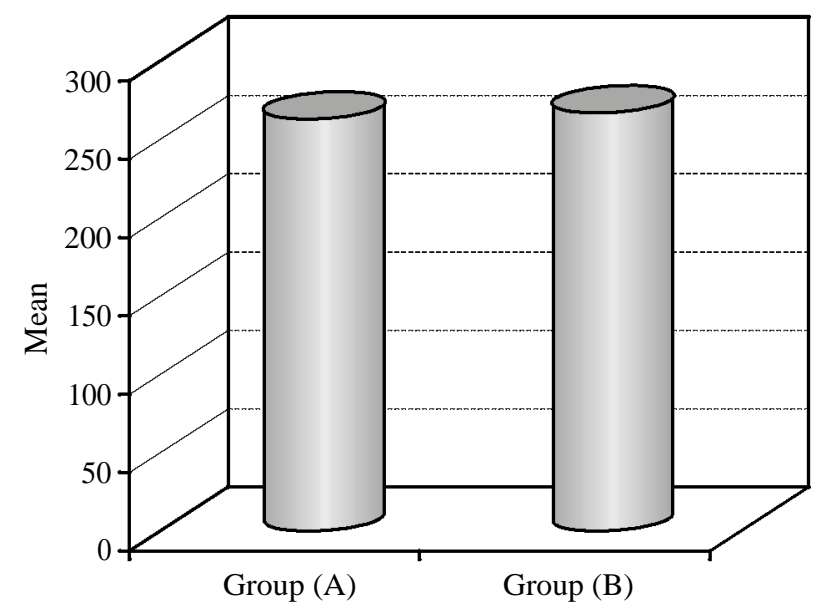

Fig. (8): Comparison between two groups as regard to patient's $2 \mathrm{HS}$ post prandial before intervention. 


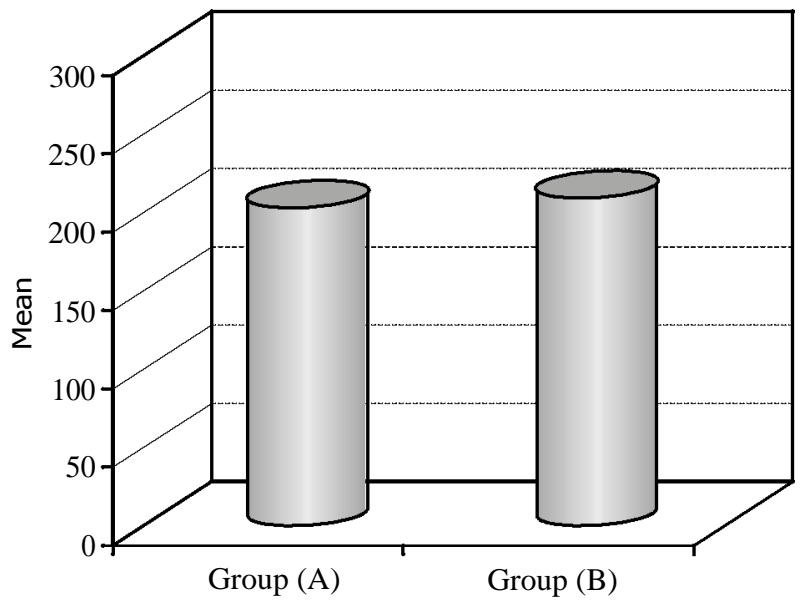

Fig. (9): Comparison between two groups as regard to patient's $2 \mathrm{HS}$ post prandial after intervention.



Fig. (11): Comparison between two groups as regard to patient's Serum Insulin Level after intervention.

\section{Discussion}

The present study was designed to investigate comparison between effect of acupressure and resistive exercise on blood glucose level in type 2 diabetes.

Today, diabetes is considered as one of the main challenges of health systems around the world. Researchers believe that the prevalence of diabetes, mortality, and its associated health care costs are increasing worldwide. Results of a systematic review on 111 countries showed that in 2015 about $8.8 \%$ of the population within the age range of 20 to 29 years had diabetes, which is predicted to be increased by $10.4 \%$ by the year 2040 . Furthermore, according to the results of a previous study, the prevalence of type 2 diabetes in 2011 in the Iranian population was $9.3 \%$ and it is predicted to rise to $13.1 \%$ by the year 2030 [7]



Fig. (10): Comparison between two groups as regard to patient's Serum Insulin Level before intervention.

Uncontrolled chronic hyperglycemia caused by diabetes, is usually associated with long-term damage, deficit, or impairment in the function of various important organs, specifically eyes, kidneys, nerves, heart, and blood vessels. Different methods are available to control type 2 diabetes symptoms, such as changing lifestyle, exercising, maintaining a suitable diet, taking oral medicines, and injecting insulin [8]

Acupressure therapy, the non-invasive pressure of fingers on meridian or acupressure points is used to release endorphins in the brain, cause relaxation in muscles, reduce pain, and emanate a feeling of comfort. Also, the energy flow (qi) is increased in the body during acupressure [9]

$\mathrm{RE}$ is reported to be safe and effective in the management of T2D, the influence of different RE intensities on changes in $\mathrm{HbAlc}$, insulin, and blood glucose levels remains to be elucidated in patients with T2D. The Liu et al.'s study revealed equivocal results of RE with different intensities on modulating the diabetes biomarkers, when prescribed to the diabetic population. Additionally, no metaanalysis has compared the effects of different RE intensities on glycemic control in patients with T2D. Based on RE intensity, Liu et al., categorized the trials into low-to-moderate-intensity and highintensity subgroups and evaluated whether intensity is associated with its beneficial effects. The data collected from all available sources were included into meta-analysis and examined effective intensity of RE in controlling the $\mathrm{HbA} 1 \mathrm{c}$, insulin, and blood glucose concentrations in patients with T2D [10]

This study was conducted on sixty patients who had type 2 diabetes. Their ages ranged from 40 to 60 years. The participants were selected from 
outpatient clinic of internal medicine of luxor general hospital. Patients were randomly assigned in two equal group.

Group A (Acupressure group): This group includes 30 patients with type 2 diabetes who received acupressure therapy beside their medication, 3 minutes and repeated 3 times per session on both legs for three times per week the treatment was conducted for 12 weeks ( 3 times/week).

Group B (Resistive exercise group): This group includes 30 patients with type 2 diabetes who received resistive exercise beside their medication using dumbbell and sandbag, used for 30 minute 3 time per week for 12 week.

Body mass index, HA1C, Randomized blood glucose, fasting, 2 hour post prandial glucose level and serum insulin level were assessed for both groups before and after 12 weeks of acupressure therapy and resistive exercise.

The results of this study revealed Acupressure more effective than resistive exercise as a complementary alternative medicine can be a helpful in reducing blood glucose level and increase insulin level in type 2 diabetic patients.

Masithoh et al., [11] conducted an examination to 52 patients. They found that there was a difference in blood glucose levels on the intervention group and control group before and after the acupressure therapy was conducted. They found Acupressure therapy was significantly effective in lowering the blood glucose levels in patients with type $2 \mathrm{DM}(p=0.000,(\mathrm{x}=0.005)$ and the effect size was 1.6 (strong).

Musmuliadin et al., [12] reported that there was a significant effectiveness of both acupressure therapy and Prolanis Program. Acupressure therapy was conducted to the respondents regularly at the ST 36 of Suzanli point and feet for 3 times. Acupressure massage therapy could inhibit hyperlipidemia progression and restore neuropathy complications in patients of type $2 \mathrm{DM}$, who received regular medication, diet and exercises. And, this study concludes that acupressure therapy is a non pharmacological therapy that can reduce the progression of diabetes mellitus [13]

Schwingshackl et al., [14] demonstrated that $\mathrm{RE}$, irrespective of its intensity effectively decreases the HbA1c levels in patients, and thereby prevents diabetes-associated complications. A RCT from Italy showed both resistance and aerobic trainings lowered the $\mathrm{HbA} 1 \mathrm{c}$ to a similar extent by $0.35 \%$ and $0.40 \%$ respectively, in subjects with T2D (Bacchi et al., 2012) [15]. In contrast, another RCT from Vienna emphasized that only strength training decreased the HbA1c (1.2\%), not endurance training in T2D patients (Cauza et al., 2005). [16] Another interesting trial from India demonstrated that moderate-intensity PRT for 3 months significantly decreased HbA1c levels $(0.54 \%)$ in Asian Indians with T2D [17]

Bweir et al., both groups showed a reduction in pre- and post-exercise blood glucose and $\mathrm{HbAlc}$ values. There was no change in resting blood pressure or heart rate in either group during the course of the 10-week intervention. The group receiving resistance exercises showed significant differences in the daily pre-exercise plasma glucose readings between the beginning and end of the exercise protocol $(p<0.001)$.

\section{References}

1- American Diabetes Association. (ADA): Diagnosis and classification of diabetes mellitus. Diabetes Care, 32: S62eS67, 2009

2- ZHENG Y., LEY S.H. and HU F.B.: Global aetiology and epidemiology of type 2 diabetes mellitus and its complications. Nature Reviews Endocrinology, 14 (2): 88, 2018.

3- McGUIRE D.K., Van de WERF F., ARMSTRONG P.W., STANDL E., KOGLIN J., GREEN J.B. and AMBROSIO G.: Association between sitagliptin use and heart failure hospitalization and related outcomes in type 2 diabetes mellitus: Secondary analysis of a randomized clinical trial. JAMA Cardiology, 1 (2): 126-135, 2016.

4- BRETON M.D., CHERÑAVVSKY D.R., FORLENZA G.P., DeBOER M.D., ROBIC J., WADWA R.P. and MAAHS D.M.: Closed-loop control during intense prolonged outdoor exercise in adolescents with type 1 diabetes: The artificial pancreas ski study. Diabetes Care, 40 (12): 1644-1650, 2017.

5- CABO F., BASKWILL A., AGUARISTI I., CHRISTOPHE-TCHAKALOFF S. and GUICHARD J.P.: Shiatsu and acupressure: Two different and distinct techniques. International journal of therapeutic massage \& bodywork, 11 (2): 441-455, 2018.

6- BWEIR S., AL-JARRAH M., ALMALTY A.M., MAAYAH M., SMIRNOVA I.V., NOVIKOVA L. and STEHNO-BITTEL L.: Resistance exercise training lowers HbA1c more than aerobic training in adults with type 2 diabetes. Diabetology \& Metabolic Syndrome, 1 (1): 1127-1135, 2009.

7- OGURTSOVA K., da ROCHA FERNANDES J.D., HUANG Y., LINNENKAMP U., GUARIGUATA L., CHO N.H., CAVAN D., SHAW J.E. and MAKAROFF L.E.: IDF Diabetes Atlas: Global estimates for the prevalence of diabetes for 2015 and 2040. Diabetes Res. Clin. Pract. Jun., 128: 740-750, 2017.

8- PICKUP J.C., REZNIK Y. and SUTTON A.J.: Glycemic Control During Continuous Subcutaneous Insulin Infusion Versus Multiple Daily Insulin Injections in Type 2 Dia- 
betes: Individual Patient Data Meta-analysis and Metaregression of Randomized Controlled Trials. Diabetes Care. May, 40 (5): 715-722, 2017.

9- SONG H.J., SEO H.J., LEE H., SON H., CHOI S.M. and LEE S.: Effect of self-acupressure for symptom management: A systematic review. Complement Ther. Med. Feb., 23 (1): 68-78, 2015.

10- TURNER D., LUZIO S., GRAY B.J., DUNSEATH G., REES E.D., KILDUFF L.P. and BRACKEN R.M.: Impact of single and multiple sets of resistance exercise in type 1 diabetes. Scandinavian journal of medicine \& science in sports, 25 (1): e99-e109, 2015.

11- MASITHOH R.F., ROPI H. and KURNIAWAN T.: Pengaruh Terapi Akupresur Terhadap Kadar Gula Darahpada Pasien Penyakit Dalam RS Tk II Dr. Soedjono Magelang. Journal of Holistic Nursing Science, 3 (2): 26-37, 2016.

12-MUSMULIADIN R., PUJIASTUTI S.E. and RUMOHORBO H.: The Influence of Acupressure Therapy (A Study on Health in Ambalawi). WMJ (Warmadewa Medical Journal), 3 (2): 38-47, 2018.

13- LEE A-L., CHEN B-C., MOU C-H., SUN M-F., YEN HR.: Association of traditional Chinese medicine therapy and the risk of vascular complications in patients with type II diabetes mellitus: A nationwide, retrospective, Taiwanese-registry, cohort study. Medicine, 95 (3), 2016.

14- SCHWINGSHACKL L., MISSBACH B., DIAS S., KÖNIG J., HOFFMANN G., 2014.

15- BACCHI E., NEGRI C., ZANOLIN M.E., MILANESE C., FACCIOLI N., TROMBETTA M., ZOPPINI G., CEVESE A., BONADONNA R.C. and SCHENA F.: Metabolic effects of aerobic training and resistance training in type 2 diabetic subjects: A randomized controlled trial (the RAED2 study). Diabetes Care, 35: 676-682, 2012.

16- CAUZA E., HANUSCH-ENSERER U., STRASSER B., LUDVIK B., METZ-SCHIMMERL S., PACINI G., WAGNER O., GEORG P., PRAGER R. and KOSTNER K.: The relative benefits of endurance and strength training on the metabolic factors and muscle function of people with type 2 diabetes mellitus. Arch. Phys. Med. Rehabil., 86: 1527-1533, 2005.

17- MISRA A., ALAPPAN N.K., VIKRAM N.K., GOEL K., GUPTA N., MITTAL K., BHATT S. and LUTHRA K.: Effect of supervised progressive resistance exercise training protocol on insulin sensitivity, glycemia, lipids and body composition in Asian Indians with type 2 diabetes. Diabetes Care, 31: 1282-1287, 2008.

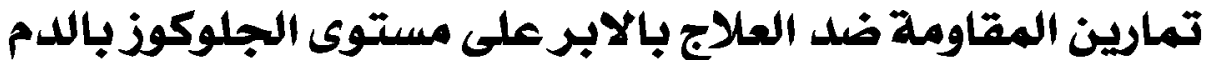

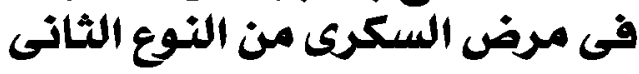

$$
\begin{aligned}
& \text { هدف من البحث: هدفت الدراسة إلى المقارنة بين تآثيرها التمارين المقاومة والعلاج بالضغط على مستىى الجلوكوذ فى الدم فى مرض } \\
& \text { السكرى من النوع r. } \\
& \text { هذه دراسة تجريبية إكلينية أجريت فى العيادة الخارجية بمستشفى الأقصر العام على .7 مريضاً من الرجال والنساء المصابين بداء } \\
& \text { السكرى من النوع r مقسمة إلى مجموعتين: }
\end{aligned}
$$

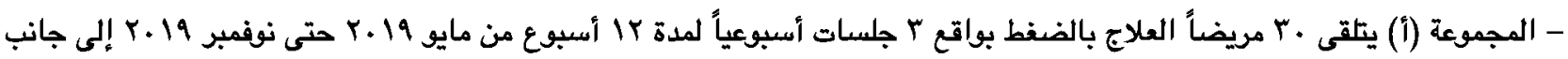

$$
\begin{aligned}
& \text { العلاج الطبى. } \\
& \text { - المجموعة (ب) يتلى • r مريضاً تمارين مقاومة بواتع r جلمات أسبوعياً لمدة rا أسبوع إلى جانب العلاج الطبى. } \\
& \text { وقدّ أظهرت النتائج ما يلى: } \\
& \text { هناك مزيد من التحسن فى المرضى الذين عق لجوا بالضفط (أ) أكثر من هؤلاء المرضى الذين عولجوا بتمارين المقاومة (ب) كما يتضح }
\end{aligned}
$$

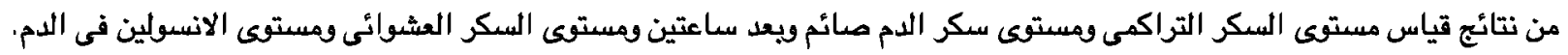

